\title{
励起準位を用いた面発光レーザーの動作温度範囲拡大
}

\author{
角田 健，宮本 智之 \\ 東京工業大学 精密工学研究所 (厂226-8503 神奈川県横浜市緑区長津田町4259-R2-39)
}

\section{Expansion of Operating Temperature Range of VCSELs Using Excited Quantized Level}

\author{
Ken TSUNODA and Tomoyuki MIYAMOTO \\ Precision and Intelligence Lab., Tokyo Institute of Technology, R2-39, 4259 Nagatsuta, Midori-ku, Yokohama, Kanagawa 226-8503
}

(Received March 24, 2015)

\begin{abstract}
The operating temperature range expansion of the vertical cavity surface emitting semiconductor lasers (VCSELs) was investigated by the optical gain spectral broadening method applying the excitation quantized level of the quantum well. From the design of the quantum well structure using the excitation level, the well width of $11-13 \mathrm{~nm}$ is appropriate in AlGaAs/GaAs system. Two types of VCSELs using the excitation level were fabricated based on the numerical design. The operation temperature range difference of $\Delta \mathrm{T}=269^{\circ} \mathrm{C}$ and $275^{\circ} \mathrm{C}$ were observed by a low temperature range design and a high temperature range design devices, respectively.
\end{abstract}

Key Words: Semiconductor laser, VCSEL, Temperature characteristics, Quantum well, Excitation quantized level

1. はじめに

半導体レーザーの一つである垂直共振器型面発光レー ザー(Vertical Cavity Surface Emitting Laser:VCSEL) $)^{1)}$ は, 低電力，単一縦モード，2次元アレーといった特徵から， 近年その応用範囲は，通信，センシング，イメージン グ，エネルギーなど多様化している。この中でも, 自動 車内に打ける光通信 ${ }^{2}$ や, 風力発電に打㤞全装置の センシング3), 人工衛星内通信 ${ }^{4)}$ など, これまで実用化 されている室内利用の短距離光通信やレーザマウスなど の応用とは異なる, 過酷な条件でVCSELを用いる研究 開発が活発化している。このような多様かつ過酷な環境 での利用を踏まえると, 光源にはこれまでよりも非常に 広い温度範囲の動作が必要になると考えられる。例え ば, 車載では車室内搭載で $-40 \sim 80^{\circ} \mathrm{C}$, エンジンルーム 内搭載で-40 $120^{\circ} \mathrm{C}$ が求められ, 他の過酷な環境も同 等範囲以上の動作が要求される.

半導体レーザーの温度特性は, 利得スペクトル特性に 強く依存するが, 利得スペクトルのピーク特性だけを考 えれば, 極低温 $\left(77 \mathrm{~K}\right.$ 以下) から $200^{\circ} \mathrm{C}$ 以上の温度差 $300^{\circ} \mathrm{C}$ 超える非常に広い温度範囲で動作可能であ る5)。このためほぼ利得ピーク波長で発振するファブリ ペローレーザーは, 縦モード跳び(モードホップ)は生じ るが，非常に広い温度範囲で動作可能である。しかし， VCSELを含む単一縦モード動作レーザーは, 発振波長 と利得スペクトルの波長関係が温度により大きく変化 し, 動作可能な温度範囲は温度差 $100-150^{\circ} \mathrm{C}$ 程度と狭く
なる。

動作温度範囲拡大には，主に2つの手法がある。1つは 利得スペクトル帯域の有効利用であり，低共振器損失で 低利得範囲を利用するか，利得を大きくする，損失低減 は他の特性改善にも有効だが ${ }^{6)}$, 低減余地は小さい。利 得増加には多重量子井戸化が有効である7,8)。ただし VCSELは, 1波長相当の入共振器を構成し，光の定在波 の腹に量子井戸を設置するために，井戸数は最大 $3-5$ 層 に制限される。歪量子井戸も利得増加に有効だが9,10), 多重化による歪蓄積が課題である。もう1つは利得スペ クトル帯域の拡大であり, 異なる波長の量子井戸の積層 が報告されている ${ }^{11,12)}$ 。ただし, 最長波長の井戸は1層 分となってしまい, 利得低下によるレーザー特性劣化要 因になる。また, 厚い $2 \lambda$ 共振器を用いた井戸数増加に よる動作温度範囲拡大も報告されているが13)，各井戸層 へのキャリア不均一注入や光子寿命増加による高速変調 制限などが課題となる。このため通常のVCSEL構造を 出来るだ維持した，量子井戸多重化とは異なる利得増 加あるいは利得スペクトル帯域増加が必要である。その 他に，MEMS構造として形成した梁上の反射鏡の変位に よる共振波長制御法を応用し，温度によらず利得スペク トルピーク波長で動作する手法が検討されている。デバ イス構造は複雑だが, ファブリペローレーザーに近い特 性となるため，実際の動作報告が待たれる ${ }^{14)}$.

本研究では, 井戸数を増加せずに実効的な利得スペク トル特性を改善する量子井戸の励起準位利用を提案し, 面発光レーザーの動作温度範囲として，実験的に温度差 
$250^{\circ} \mathrm{C}$ 以上を達成したので報告する。第2節では, 励起 準位利用量子井戸の基本設計を述べ，第3節では，利得 特性としきい值電流の解析結果を示す。第4節で面発光 レーザーの製作とその評価結果を示し，第5節で結論を 述べる.

\section{2. 励起準位利用による利得スペクトル帯域拡大}

\section{1 励起準位利用量子井戸の設計指針}

通常のVCSELは, Fig. 1のように共振波長を室温近傍 で利得ピーク近くに設計する。高温では，バンドギャッ プエネルギー $(E \mathrm{~g})$ が減少し, 利得スペクトル $(\lambda \mathrm{g})$ は長 波長シフトする。このため共振波長の利得が減少するの で, しきい值利得 $\left(g_{\mathrm{th}}\right)$ を得るために注入キャリア密度 $(N)$ の増加が必要である。ささらに高温になると, キャリ ア漏れや自己発熱のため利得増加が抑制され発振が不可 となる。一方, 低温では $\lambda \mathrm{g} か ゙$ 短波長化することで, 共 振波長の利得が得られなくなり発振が不可となる。な お, 詳細には利得スペクトルは温度係数 $0.3 \mathrm{~nm} / \mathrm{K}$ 程度で 変化するが, 同時に共振波長も温度係数 $0.07 \mathrm{~nm} / \mathrm{K}$ 程度 で変化する。

以上の利得特性において, 量子井戸の短波長側利得を 増加できれば，高温でのキャリア密度増加を抑制でき る。エネルギー分布はフェルミ・ディラック分布になる ので, 短波長側利得の増加には状態密度の増加が必要で ある。そこで励起準位エネルギーの状態密度が基底準位 の2倍相当になることを利用する。この場合でもエネル ギー分布が影響するので，基底準位と励起準位間のエネ ルギー差の設定が重要になる. Fig. 2 に基底準位と励起 準位のエネルギー差 $\Delta E_{12}$ と利得帯域の関係を概念図で示

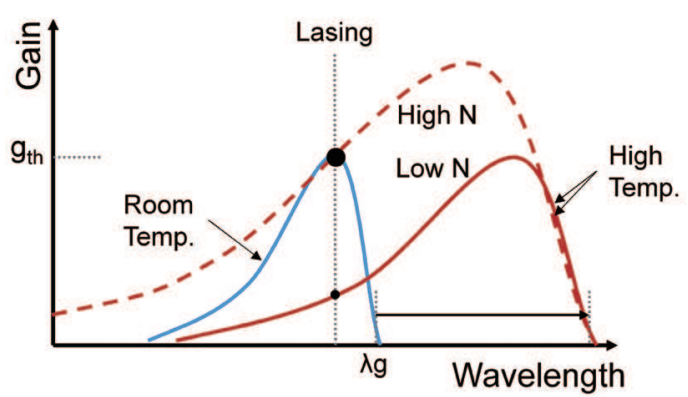

Fig. 1 Schematic relation between lasing wavelength and gain spectra in VCSEL. Blue line shows gain at room temperature, and red lines show gain at high temperature.

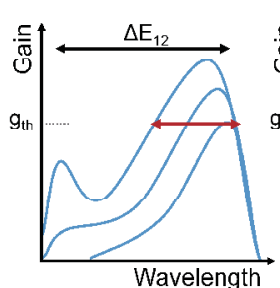

(a)

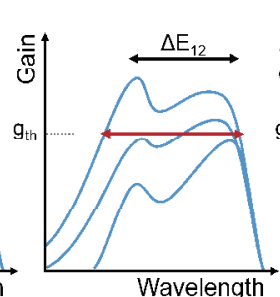

(b)

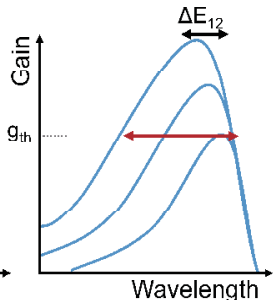

(c)
Fig. 2 Schematic gain spectra for various carrier injection level. (a) large excited level energy, (b) suitable excited level energy, (c) small excited level energy.
す.

Fig. 2 (a) は $\Delta E_{12}$ が大きい場合で，通常の量子井戸の設 計に相当する。基底準位のみにキャリアが蓄積するた め, 低注入キャリア密度で利得を得られるが, 励起準位 利得を得るには非常に大きな注入キャリア密度が必要に なるので，実効的には基底準位に基づく利得スペクトル 帯域になる。

Fig. 2 (b) は $\Delta E_{12}$ が適度な大きさの場合で, 比較的少な いキャリア密度で励起準位利得が得られ，基底準位利得 と合わせて利得スペクトルの広帯域化が可能になる。

一方で, Fig. 2 (c)のように $\Delta E_{12}$ が小さい場合は, 利得 スペクトル帯域の拡大は十分に出来ない.

\section{2 励起準位利用井戸構造の設計}

励起準位の制御には，井戸幅とバリア高さを用いる。 特にバリア高さは, 励起準位からバリア層へのキャリア 漏れの影響も考慮する必要がある.

Fig.3は，製作する面発光レーザーを想定したAlGaAs/ $\mathrm{GaAs}$ 系量子井戸について, 横軸にAlGaAsバリア層の $\mathrm{Al}$ 組成を, 縦軸にGaAs井戸幅を取り, 遷移波長をカラー マップで示した。遷移波長は伝導帯と価電子帯の第1励 起準位間エネルギーとして求めた。量子化エネルギーは 有効質量近似より求め, 材料物性は参考文献15)の值を 用いた。なお，次の議論は，価電子帯の基底一励起準位 間エネルギーは比較的に小さいため，伝導帯のみを考慮 した。

フェルミ・ディラック分布を考慮すると, 伝導帯の基 底一励起準位間エネルギー $\left(\Delta E \mathrm{c}_{12}\right)$ は2 $-3 k T(0.05-0.08 \mathrm{eV})$ が適切である。なお， $k$ はボルツマン定数，Tは室温程度 を考えている。バリア層へのキャリア漏れ抑制には，励 起準位 $\left(E \mathrm{c}_{2}\right)$ とバリア端 $\left(E \mathrm{c}_{\mathrm{b}}\right)$ の差 $\left(E \mathrm{c}_{\mathrm{b}}-E \mathrm{c}_{2}\right)$ が $0.1 \mathrm{eV}$ 程度 が必要と考える。結果として，影を付けた範囲が励起準 位利用に適当な構造と考えられ，井戸幅11-13 nmと通 常の量子井戸の6-8 nmに比べて 1.5 倍ほど厚い。なお, 井戸層の材料により制御は可能だが，井戸幅が制限され るため, 通常の量子井戸よりも特に長波長への発光波長

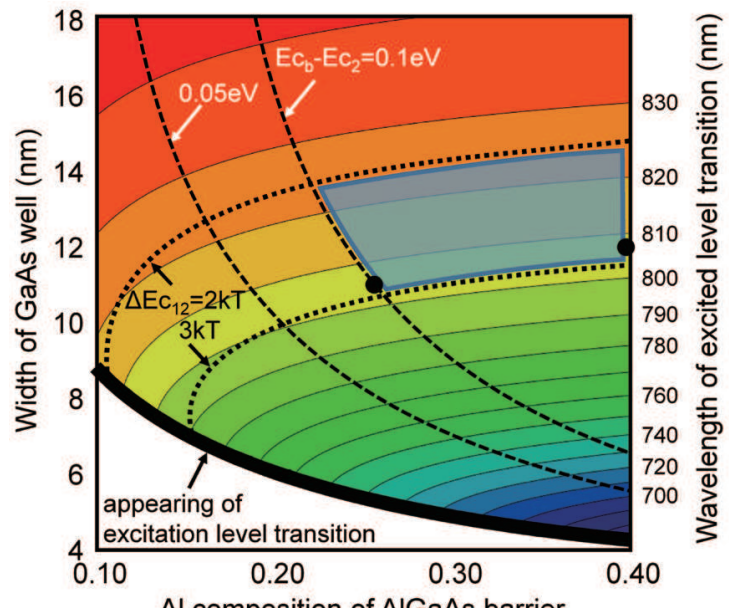

Fig. 3 Transition wavelength of excitation level. Suitable structure is shown as shaded blue area and solid circles shows fabricated structures. 
拡大は制限される。

\section{3. 励起準位利用構造の利得としきい值特性解析}

\section{1 利得スペクトルの理論解析}

井戸構造の設計をもとに，まず利得スペクトルを解析 した。例として, Fig. 4に $\mathrm{Al}_{0.25} \mathrm{Ga}_{0.75} \mathrm{As} / \mathrm{GaAs}$ で井戸幅 $11 \mathrm{~nm}$ の構造について, 注入キャリア密度 $1 \times 10^{19} \mathrm{~cm}^{-3}$ の 解析結果を示す。また, 通常の量子井戸相当として, 井 戸幅8 $\mathrm{nm}$ の結果も示した。 なお, 量子井戸の利得スぺ クトルは, 式(1)で解析した ${ }^{16)}$.

$$
\begin{aligned}
G(N, E)= & \frac{E}{n \hbar} \sqrt{\frac{\mu_{0}}{\varepsilon_{0}}} \int_{0}^{\infty} R_{c h}\left(E_{c v}\right)^{2} \cdot g_{c v}\left(E_{c v}\right) \times \\
& \left\{f_{c}\left(E_{c v}\right)-f_{v}\left(E_{c v}\right)\right\} \frac{\hbar / \tau_{i n}}{\left(E-E_{c v}\right)^{2}+\left(\hbar / \tau_{i n}\right)^{2}} d E_{c v}
\end{aligned}
$$

ここで，Gは線形利得定数，Nはキャリア密度， $E$ は光 子エネルギー, $n$ は屈折率 $(n=3.6), \hbar$ ॠプランク定数, $\mu_{0}$ は真空透磁率, $\varepsilon_{0}$ は真空誘電率, $E_{c v}$ はキャリア遷移工 ネルギー, $R_{c h}$ は遷移行列要素, $g_{c v}$ は換算状態密度, $f_{c}$ と $f_{v}$ は伝導帯と価電子帯の擬フェルミレベルに対するフェ ルミ・ディラック分布関数, $\tau_{i n}$ はバンド内緩和時間 $\left(\boldsymbol{\tau}_{\text {in }}=0.1 \mathrm{ps}\right)$ である.

Fig. 4より励起準位利用構造 $(11 \mathrm{~nm})$ の $\Delta \mathrm{E}_{12}$ は通常構造 $(8 \mathrm{~nm})$ よりも小さくなり, 比較的低注入キャリア密度 から励起準位の利得が大きくなる。さらに, 通常構造で は励起準位と基底準位の間の利得の低下が大きい。これ はフェルミ・ディラック分布関数形状とダイポールモー メントのエネルギー依存性に基づくが, この利得低下領 域をしきい值利得に高めるにも, 注入キャリア密度の増 加が必要になる。以上から, 励起準位を適切に利用する 量子井戸構造により, 広い利得スペクトル帯域を過㮃な 注入キャリア密度の増加なく得られることがわかる.

\section{2 励起準位利用VCSELのしきい值特性}

利得特性からVCSELのしきい值電流密度の温度特性 を理論解析した。解析では, 注入キャリアのバリア層へ の漏れも考慮した，具体的には，伝導帯の量子井戸内の 擬フェルミレベルをバリア層にも延長して漏れキャリア

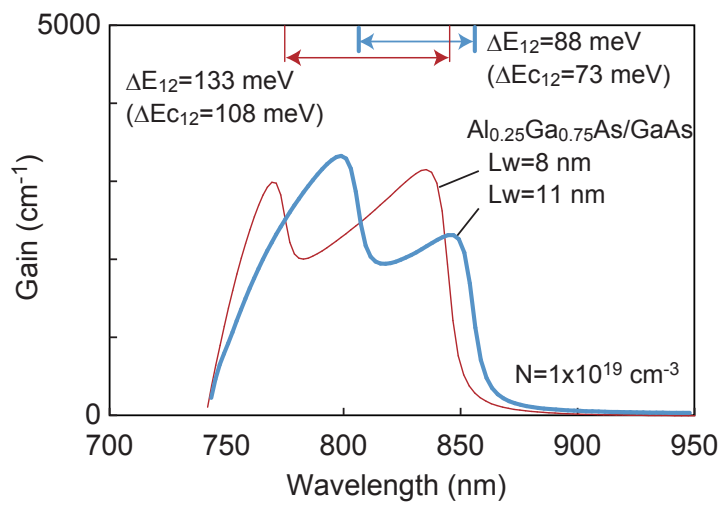

Fig. 4 Gain spectrum of (bold line) $11 \mathrm{~nm}$ quantum well and (thin line) $8 \mathrm{~nm}$ well.
を考慮した。ただし簡易のため，井戸とバリアにおける 電子とホールのキャリア密度不均衡によるポテンシャル 変形は考慮していない。共振器構造は, 平均反射率 $99.74 \%$ ，吸収損失と回折損失はそれぞれ $10 \mathrm{~cm}^{-1}$ とし， これらの温度依存性はないものした。また，井戸数は3 とし，光閉じ込め係数への定在波分布の影響を考慮し た。

しきい值電流密度には，共振波長と利得スペクトルの 波長関係(波長オフセット)も影響する。そこでさまざま な共振波長設定に対する，しきい值電流密度の温度依存 性を解析した。 Fig. 5に室温で設定する共振波長を縦軸 に, 横軸を温度とした, しきい值電流密度の解析結果を カラーマップで示す.

発振動作上限を $6 \mathrm{kA} / \mathrm{cm}^{2}$ と考えると，共振波長を室温 で基底準位に設定した構造に相当するグラフ上端では, 室温近傍から $250^{\circ} \mathrm{C}$ 程度まで動作可能となり，高温側に 適した設計といえる。一方，共振波長を室温で励起準位 近傍に設定した構造に相当するグラフ下端では, $-200^{\circ} \mathrm{C}$ 程度から $100^{\circ} \mathrm{C}$ 程度まで動作可能となり, 低温側 に適した設計となる。このように利用する温度帯域によ り，適切な構造の設定にすることで，温度差 $200^{\circ} \mathrm{C}$ 以上 の動作温度範囲の拡大が期待できる。なおグラフには, 長波長に共振波長を設定した場合に，温度 $100^{\circ} \mathrm{C}$ 近傍 で，基底準位から励起準位への発振波長移行によるしき い值電流密度の一旦低下が示唆されている。ただ, こ れは共振器特性によっては明瞭にならない。

\section{4. 励起準位利用構造デバイスの製作と特性評価}

4.1 低温側温度範囲拡大構造のレーザー特性

設計を基本にまず低温側温度範囲拡大構造の VCSELを製作および特性評価した。ウェ八構造は半導 体の多層膜反射鏡 (Distributed Bragg Reflector: DBR) を $\mathrm{Al}_{0.3} \mathrm{Ga}_{0.7} \mathrm{As} / \mathrm{Al}_{0.9} \mathrm{Ga}_{0.1} \mathrm{As}$ 組成で下部40.5ペア, 上部25ペア とし，活性層は $\mathrm{Al}_{0.25} \mathrm{Ga}_{0.75} \mathrm{As} / \mathrm{GaAs}$ で井戸幅 $11 \mathrm{~nm}$ の井戸 層とした。室温における共振波長は第一励起準位近傍 $(808 \mathrm{~nm})$ とした。なお，活性層直上のDBRに

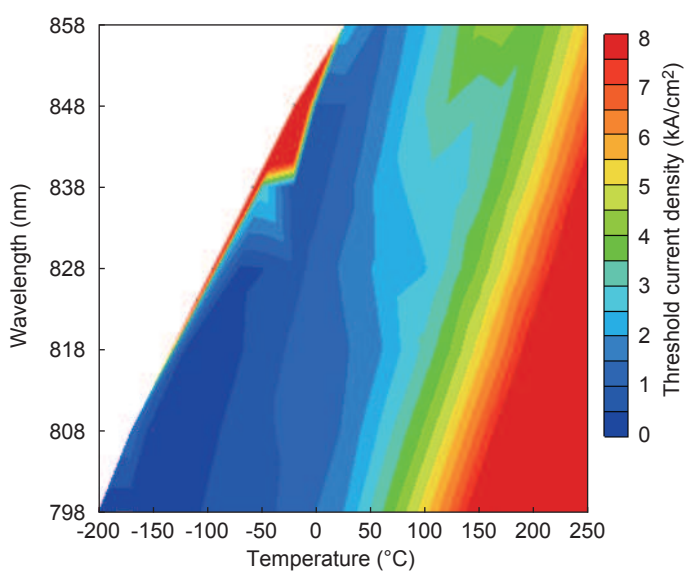

Fig. 5 Analysis of threshold current density of VCSEL using excited level. High temperature range shows high threshold current density. 
$\mathrm{Al}_{0.98} \mathrm{Ga}_{0.02} \mathrm{As}$ の選択酸化層 $30 \mathrm{~nm}$ 層挿入した。製作プ ロセスは我々の通常のVCSEL製作プロセスを適用し， メササイズ $30 \mu \mathrm{m}$ 角, 非酸化開口径5-6 $\mu \mathrm{m}$, 光出射空 $10 \mu \mathrm{m}$ 角とした。測定はcwとした。

低温環境における測定は, 液体窒素を用いて $-196^{\circ} \mathrm{C}$ から $0^{\circ} \mathrm{C}$ 近傍まで評価し, それ以上の温度範囲は温風機 で加熱し評価した. Fig. 6に測定した電流一光出力特性 の例を示す。しきい值を持つレーザー発振動作が得ら れ, 測定電流範囲のほとんどで $0.5 \mathrm{~mW}$ 以上の出力が得 られている。

また, 光出力特性からしきい值電流を抽出した結果を Fig. 7に示す。 $-196^{\circ} \mathrm{C}$ か $73^{\circ} \mathrm{C}$ ま゙の発振が得られ, 動

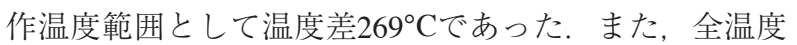
範囲で $2.5 \mathrm{~mA}$ 以下の低しきい值電流動作となり, 最大と 最小のしきい值電流の比として 2.3 とう小さなしきい 值変動であった

ここで，本デバイスは広い温度範囲で動作させるた め, 設定した共振波長以外へのモードホップの可能性も 検討する必要がある. Fig. 8にスペクトルの温度特性の 測定結果を示す。高温ほど発振波長が長波長にシフトし ているが，単一縦モードとして発振が得られていること を確認した。Fig.9に発振波長の温度依存性を示す。発 振波長はほぼ単調増加していることがわかる。 $-91^{\circ} \mathrm{C}$

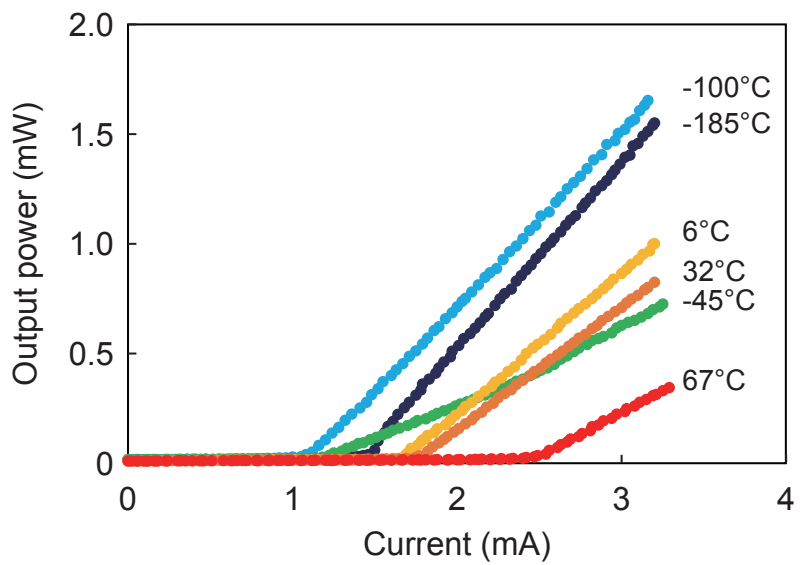

Fig. 6 I-L characteristics of low temperature range design device under various temperature.

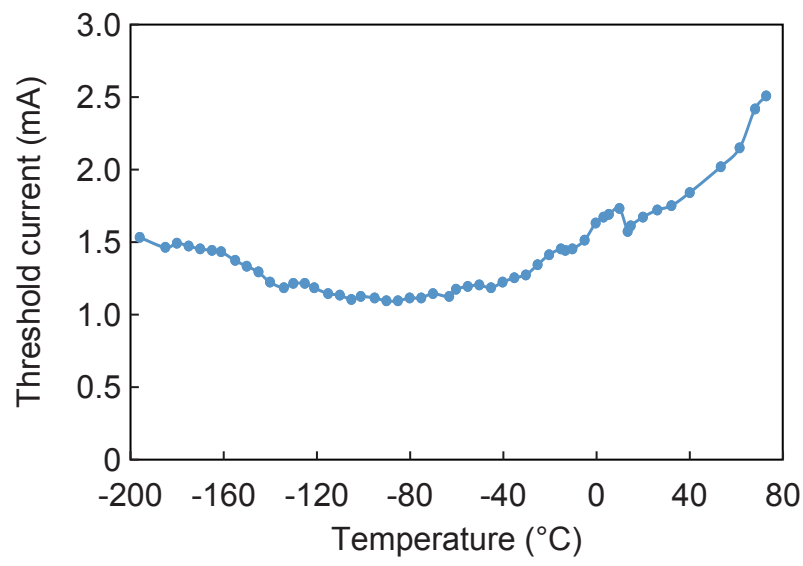

Fig. 7 Threshold current characteristics of low temperature range design device.
から $31^{\circ} \mathrm{C}$ の範囲を直線近似すると $0.059 \mathrm{~nm} / \mathrm{K}$ となる。一 方, $-150^{\circ} \mathrm{C}$ 以下の範囲で発振波長の変化率が減少して いるが, これは，バンドギャップエネルギーの温度変化 を表すバルシューニの経験式 ${ }^{17)}$ から，バンドギャップの 変化が低温域で減少する効果が屈折率にも影響している ことのほか，スペクトル測定において，デバイスに付着 した液体窒素の残留のために，デバイスと温度測定部の 間にわずかに温度差が生じた可能性もあると考えてい る.

\section{2 高温側温度範囲拡大構造のレーザー特性}

次に, 高温側温度範囲拡大構造のVCSELを製作およ び評価した。 ウェハ構造は, $\mathrm{DBR} は \mathrm{Al}_{0.2} \mathrm{Ga}_{0.8} \mathrm{As} / \mathrm{Al}_{0.9} \mathrm{Ga}_{0.1} \mathrm{As}$ 組成で下部40.5ペア，上部21ペアとし，活性層は $\mathrm{Al}_{0.4} \mathrm{Ga}_{0.6} \mathrm{As} / \mathrm{GaAs}$ で井戸幅 $12 \mathrm{~nm}$ の4井戸層とした。共振 波長は基底準位の波長 $(856 \mathrm{~nm})$ から $10 \mathrm{~nm}$ 短波側に設計 し，室温以下もある程度の温度範囲の動作を可能とし た。プロセスとデバイスサイズは，低温側温度範囲拡大 構造と同等で, 非酸化開口径は6 $\mu \mathrm{m}$ である。測定はcw とした

低温側は液体窒素を用いて $-196^{\circ} \mathrm{C}$ から，高温側はセ ラミックヒーター上にデバイスを搭載したマウントを設 置して， $150^{\circ} \mathrm{C}$ 以上まで評価可能とした。Fig. 10にしき い值電流の測定結果を示す。なお，低温側測定と高温側 測定で，同一ウェハで同一プロセスに基づくが，異なる

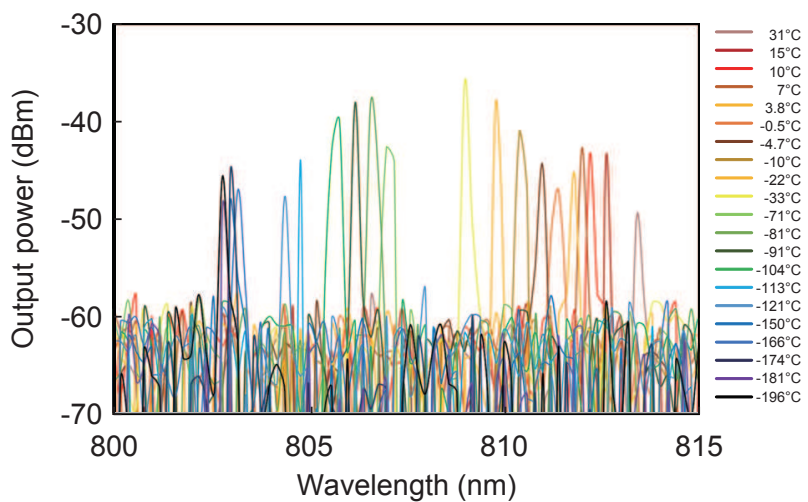

Fig. 8 Spectrum characteristics of low temperature range design device. The lasing wavelength at high temperature is long.

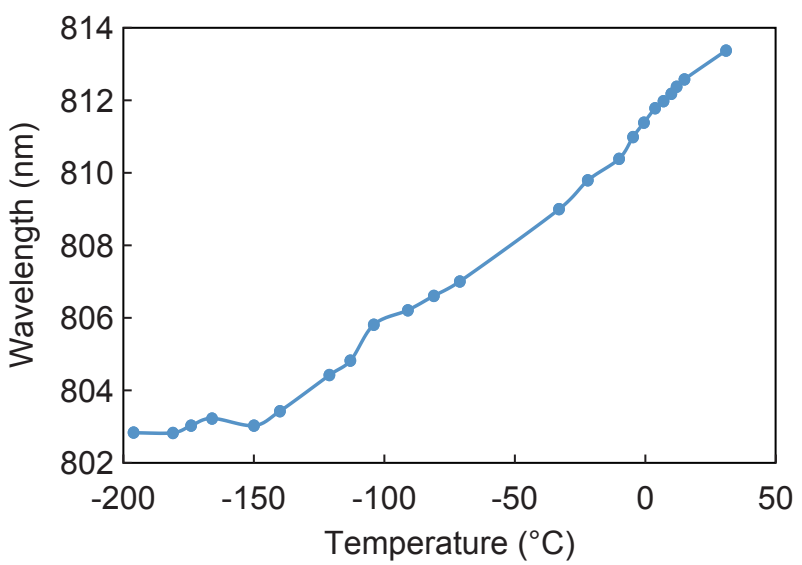

Fig. 9 Temperature characteristics of lasing wavelength of low temperature range design device. 


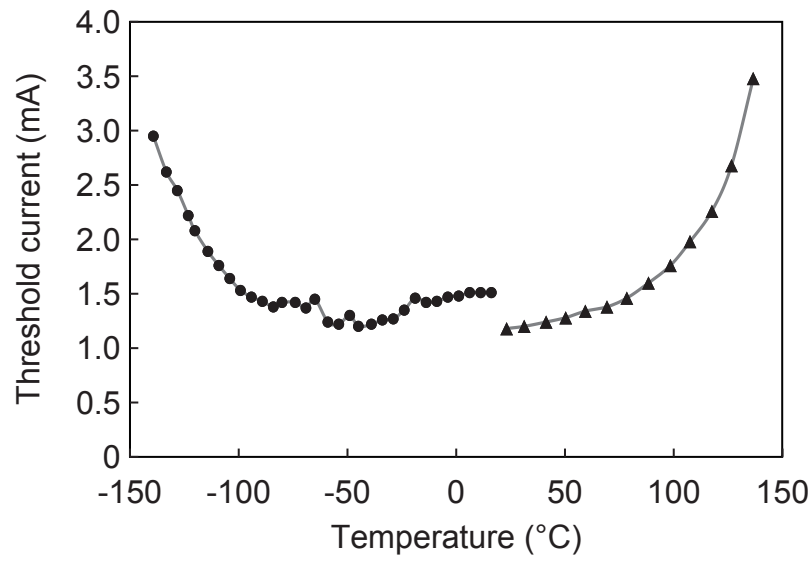

Fig. 10 Threshold current characteristics of high temperature range design device. Two kind of markers show measurement results under different system.

デバイスの測定結果を示している。このデバイス間の特 性の違いは十分小さいと考えている. $20^{\circ} \mathrm{C}$ 近傍のしき い值の跳びは, 低温側測定において, 測定系への結露に よる水分が不要な電流パスになったことが原因と考えて いる.

Fig. 10 より $-140^{\circ} \mathrm{C}$ か $135^{\circ} \mathrm{C}$ での温度差 $275^{\circ} \mathrm{C}$ 発 振となった。全温度範囲でしきい值電流 $3.5 \mathrm{~mA}$ 以下で, しきい值の最大と最小の比 2.9 と少ない変化であった。 なお，共振波長を基底準位から $-10 \mathrm{~nm}$ のオフセットと したが，想定よりも低温側に動作範囲が拡大した。これ は, ウェ八製作誤差に加え，ウェハ製作の基準とした フォトルミネッセンスピーク波長と基底準位量子化エネ ルギーにはわずかな波長差があることが影響したと考え ている.

Fig. 11に発振波長の温度依存性を示す。高温側温度範 囲拡大構造デバイスにおいてもモードホッピングは確認 されず, $-134^{\circ} \mathrm{C}$ か $20^{\circ} \mathrm{C}$ 温度特性は $0.053 \mathrm{~nm} / \mathrm{K}$, $23^{\circ} \mathrm{C}$ か $135^{\circ} \mathrm{C}$ 温度特性は $0.076 \mathrm{~nm} / \mathrm{K}$ であった。

Fig. 12は, スロープ効率の測定結果である。低温側は 結露の出力測定への影響を抑制するため, 冷却アルコー ル中にデバイスを浸した。結果から， $-80^{\circ} \mathrm{C}$ 程度から $100^{\circ} \mathrm{C}$ 程度の広い温度範囲で少ない変動が得られた。な

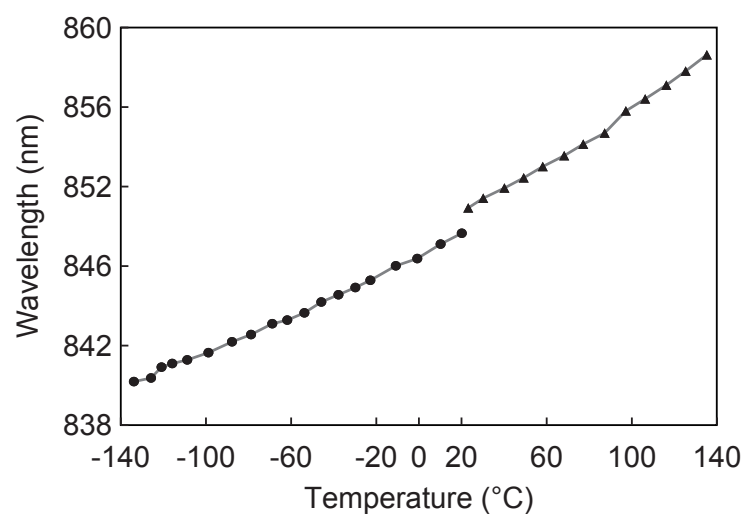

Fig. 11 Temperature characteristics of lasing wavelength of high temperature range design device. Two kind of markers show measurement results under different system.

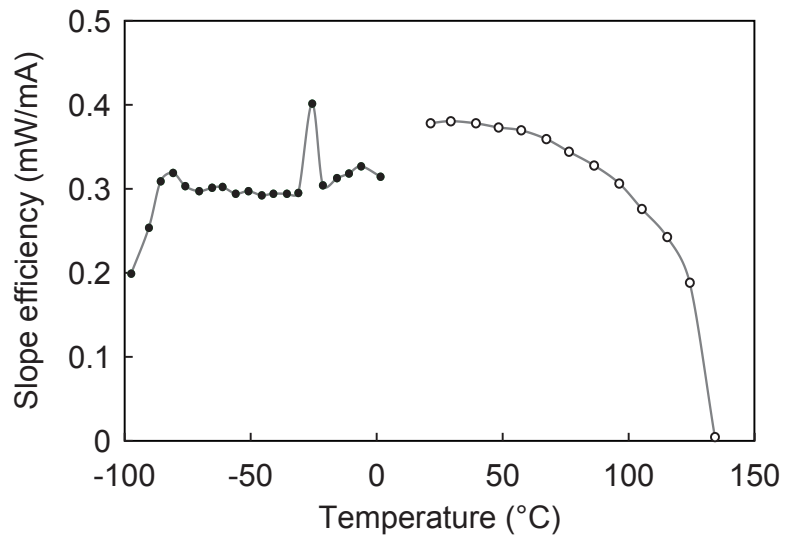

Fig. 12 Temperature characteristics of slope efficiency of high temperature range design device. Two kind of markers show measurement results under different system.

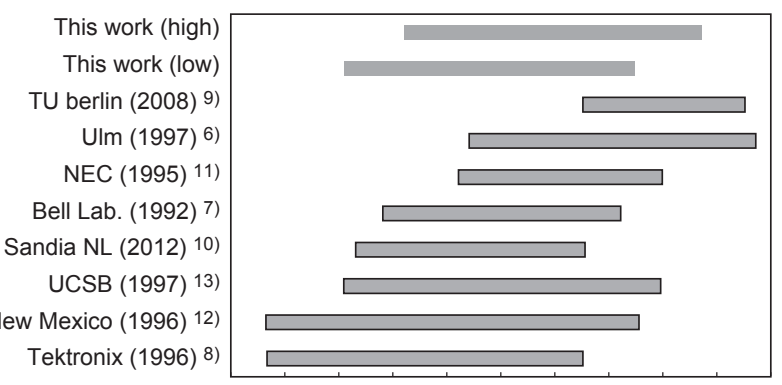

$-300-250-200-150-100-50 \quad 0 \quad 50 \quad 100 \quad 150 \quad 200$

Fig. 13 Comparison of operation temperature range.

お, $20^{\circ} \mathrm{C}$ 近傍の值の跳びは測定系の調整の影響, $-20^{\circ} \mathrm{C}$ 近傍の值の異常は，迷光によるノイズが原因と考えている.

\section{3 報告事例との比較}

Fig. 13に本研究で得られた動作温度範囲と, 比較的広 い温度範囲のVCSEL動作を報告している他研究機関の 例を示す。

励起準位を利用する本研究の結果は, 歪量子井戸を含 む多重量子井戸構造 ${ }^{7-10)}$ に比べて動作温度範囲は拡大で きたと考えている。一方で，異なる量子準位の井戸層を 積層するチャープ井戸構造 ${ }^{11,12)}$ や，2 2 共振器構造 ${ }^{13)}$ に比 べると, 動作温度範囲は同等か若干狭い。ただし, $100^{\circ} \mathrm{C}$ 超える高温側の動作を達成している。 さらに, 高温側の動作については，実効的な井戸数の多い本手法 では有利であり, 波長オフセットの調整により $200^{\circ} \mathrm{C}$ 超える動作も可能と考えている。

\section{5. 結 論}

励起準位を利用した利得スペクトル拡大による面発光 レーザーの動作温度範囲拡大を検討した。

励起準位利用の量子井戸設計では，AlGaAs/GaAs系で 井戸幅11-13 nmが適当であることを明らかにした。ま た，励起準位利用VCSELの構造設計と性能予測を行い， しきい值電流密度 $6 \mathrm{kA} / \mathrm{cm}^{2}$ を発振上限と考えると, 低温 側動作温度範囲拡大構造で温度差 $\Delta T=300^{\circ} \mathrm{C}$, 高温側動 作温度範囲拡大構造で温度差 $\Delta T=250^{\circ} \mathrm{C}$ の温度範囲が期 
待できることを示した。実際に製作したデバイスによ り, 低温側動作温度範囲拡大構造で温度差 $\Delta T=269^{\circ} \mathrm{C}$, および高温側動作温度範囲拡大構造で温度差 $\Delta T=275^{\circ} \mathrm{C}$ の単一縦モード動作を確認した。

以上より，励起準位の利用がVCSELの動作温度範囲 拡大手法として有効であることを示した。 今後，量子井 戸構造の詳細な最適化とともに共振器損失の低減などを 行うことで，より広い温度範囲での動作が可能になると 期待できる.

\section{謝 辞}

デバイス製作においてご協力いただいた東京工業大学 半導体MEMSプロセス技術センターの松谷晃宏博士に感 謝する

\section{参考文献}

1) K. Iga: IEEE J. Sel. Top. Quantum Electron. 6 (2000) 1201.

2) T. Kibler, S. Poferl, G. Bock, H.-P. Huber, and E. Zeeb: J. Lightwave Technology 22 (2004) 2184.

3) K. Worms, C. Klamouris, F. Wegh, L. Meder, D. Volkmer, S. P. Philipps, S. K. Reichmuth, H. Helmers, A.W. Bett, J. Vourvoulakis, et al.: Proc. Sensors and Measuring Systems (2014) p. 1.
4) R. F. Carson, M. E. Warren, J. R. Joseph, T. Wilcox, D. J. Abell, and K. J. Otis: Proc. SPIE 9226 (2014) 92260H.

5) T. Kageyama, K. Takada, K. Nishi, M. Yamaguchi, R. Mochida, Y. Maeda, H. Kondo, K. Takemasa, Y. Tanaka, T. Yamamoto, et. al.: Proc. SPIE 8277 (2012) 82770C.

6) R. Jager, M. Grabherr, C. Jung, R. Michalzik, G. Reiner, B Weigl, and K. J. Ebeling: Electron. Lett. 33 (1997) 330.

7) B. Tell, K. F. Brown-Goebeler, R. E. Leibenguth, F. M. Baez, and Y. H. Lee: Appl. Phys. Lett. 60 (1992) 683.

8) G. Goncher, B. Lu, W.L. Luo, J. Cheng, S. Hersee, S. Z. Sun, R. P. Schneider, and J. C. Zolper: IEEE Photon. Technol. Lett. 8 (1996) 316.

9) A. Mutig, G. Fiol, P. Moser, D. Arsenijevic, V. A. Shchukin, N. N. Ledentsov, S. S. Mikhrin, I. L. Krestnikov, D. A. Livshits, A. R. Kovsh, et al.: Electron. Lett. 44 (2008) 3105.

10) D. K. Serkland, K.M. Geib, G. M. Peake, G. A. Keeler, and A. Y. Hsu: Proc. SPIE 8276 (2012) 82760S.

11) M. Kajita, T. Kawakami, M. Nido, A. Kimura, T. Yoshikawa, K. Kurihara, Y. Sugimoto, and K. Kasahara: IEEE J. Sel. Top. Quantum Electron. 1 (1995) 654.

12) G. G. Ortiz, C. P. Hains, B. Lu, S. Z. Sun, J. Cheng, and J. C. Zolper: IEEE Photon. Technol. Lett. 8 (1996) 1423

13) Y. A. Akulova, B. J. Thibeault, J. Ko, and L. A. Coldren: IEEE Photon. Technol. Lett. 9 (1997) 277.

14) H. Sano and F. Koyama: IEICE Electron. Express 6 (2009) 883.

15) 赤崎勇:III-V族化合物半導体 (培風館, 1994) p. 150, p. 187 , p. 188.

16) M. Asada, A. Kameyama, and Y. Suematsu: IEEE J. Quantum Electron. 20 (1984) 745

17) Y. P. Varshni: Physica 34 (1967) 149. 